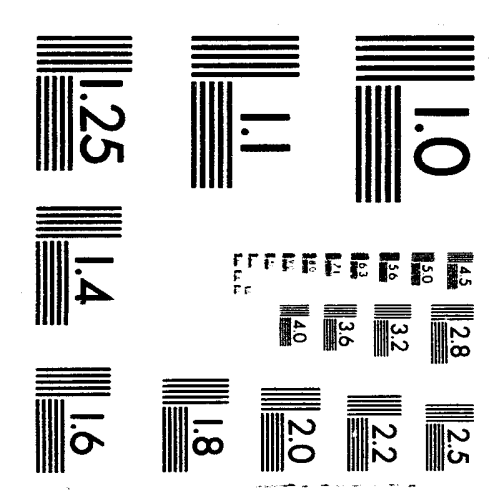



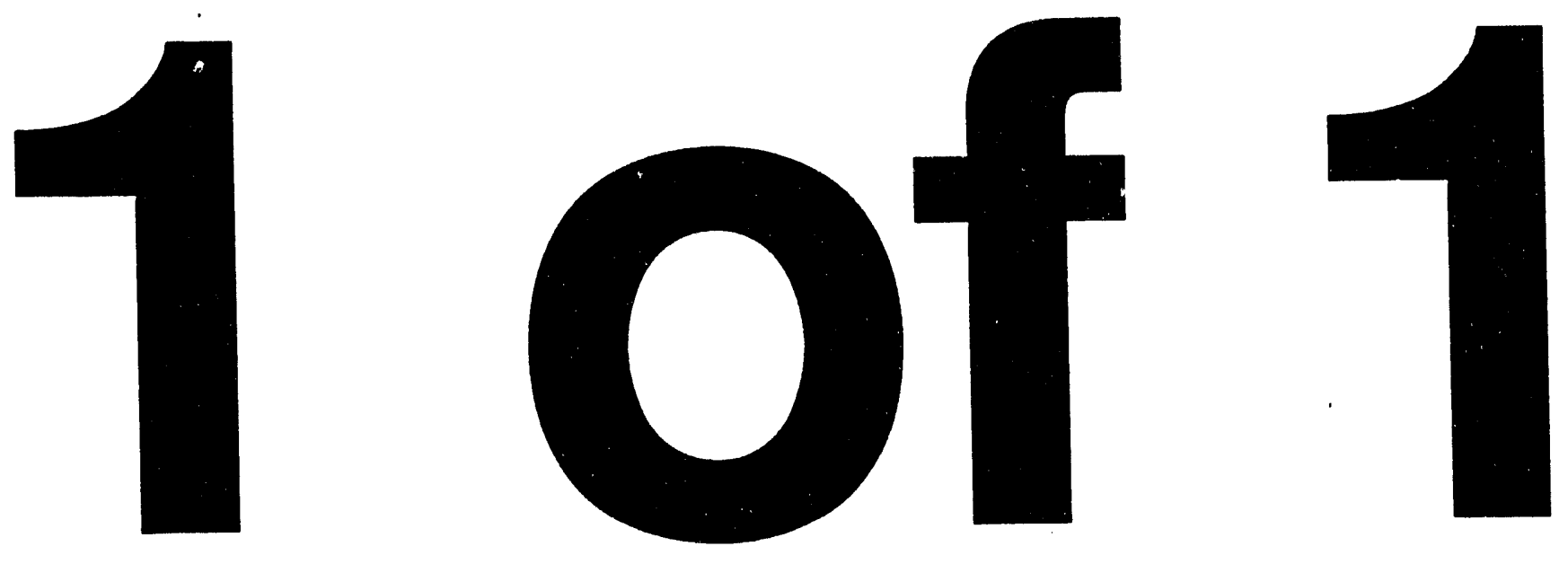


\section{RADIOLYTIC GAS GENERATION IN SALT CAKE QUALITY ASSURANCE PLAN}

by

D. D. Walker

Savannah River Site

Aiken, South Carolina 29808

This paper was prepared in connection with work done under the above contract number with the U. S.

Department of Energy. By acceptance of this paper, the publisher and/or recipient acknowledges the U. S. Govemment's right to retain a nonexclusive, royalty-free license in and to any copyright covering this paper, along with the right to reproduce and to authorize others to reproduce all or part of the copyrighted paper. 


\section{DISCLAIMER}

This report was prepared as an account of work sponsored by an agency of the United States Government. Neither the United States Government nor any agency thereof, nor any of their employees, makes any warranty, express or implied, or assumes any legal liability or responsibility for the accuracy, completeness, or usefulness of any information, apparatus, product, or process disclosed, or represents that its use would not infringe privately owned rights. Reference herein to any specific commercial product, process, or service by trade name, trademark, manufacturer, or otherwise does not necessarily constitute or imply its endorsement, recommendation, or favoring by the United States Government or any agency thereof. The views and opinions of authors expressed herein do not necessarily state or reflect those of the United States Government or any agency thereof.

This report has been reproduced directly from the best available copy.

Available to DOE and DOE contractors from the Office of Scientific and Technical Information, P. O. Box 62, Oak Ridge, TN 37831; prices available from (615) $576-8401$.

Available to the public from the National Technical Information Service, U. S. Department of Commerce, 5285 Port Royal Rd., Springfield, VA 22161 
WSRC-RP-93-1342

Keywords: High activity liquid waste, saltcakes, hydrogen

Retention time: Permanent

August 30,1993

TO: S. D. FINK, 773-A

FROM: D. B. WALKER, 773-A, C. I. CRAWFORD, 773-A, and N. E. BIBLER, 773-A

\section{RADIOLYTIC GAS GENERATION IN SALT CAKE QUALITY ASSURANCE PIAN (U)}

\section{INTRODUCTION}

High-level radioactive wastes are stored in large, steel tanks in the Savannah River Site's Tank Farms. The liquid levels in these tanks are monitored to detect leakage of waste out of tanks or leakage of liquids into the tanks. Recent unexplained level fluctuations in high-level waste (HLW) tanks have caused High Level Waste Engineering (HLWE) to develop a program to better understand tank level behavior. 1 Interim Waste Technology (IWT) has been requested ${ }^{2}$ by HLWE to obtain data which will lead to a better understanding of the radiolytic generation of gases in salt cake. A task plan has been written in response to this request. 3 This document details the controls necessary to ensure the quality of the results of the activities described in the task plan.

\section{TASK QA PLAN CHECKLIST}

See Attachment 1.

\section{ADDITIONAI COMMENTS}

$Q A$ requirements for task activities performed by other organizations are specified in the Critical Measurements section of the Task Technical Plan. 3

\section{DOCUMENTS REQUIRING CUSTOMER APPROVAL}

The following document requires customer approval:

1. D. D. Walker, C. L. Crawford, and N. E. Bibler, "Radiolytic Gas Generation in Salt Cake, Technical Task Plan (U)," WSRC-RP-93-1341, August 29, 1993. 
ATTACHMENT 1. Task QA Plan Checklist

Task Tille:_Radiolytic Gas Generation in Sall Cake

Task Technical Plan Document No: WSRC-RP-93-1341

Listed below are the 20 sections of WSRC 1Q. Check WSRC 10 Sections applicable to the task Further indicate by check marks. DWP\&HT procedures used to control the lask This checklist identifies only the procedures used to control task activities performed by DWP\&HT.

\begin{tabular}{|c|c|c|c|}
\hline WSRC $1 Q$ Section & $\begin{array}{l}\text { Applles } \\
\text { to Task }\end{array}$ & DWP\&IIT QA Procedures & $\begin{array}{l}\text { DWP\&HT } \\
\text { Procedure Used }\end{array}$ \\
\hline Organization & $\mathrm{x}$ & $\begin{array}{l}\text { DWP\&HT } 1-1 \text {, Organization } \\
\text { DWP\&HT } 1-2 \text {, Stop Work }\end{array}$ & $\begin{array}{l}\mathbf{x} \\
\mathbf{x}\end{array}$ \\
\hline QA Program & $\mathrm{x}$ & \begin{tabular}{|l} 
DWP\&HT $2-1$, Quality Assurance Program \\
DWP\&HT 2-2, Training Program \\
DWP\&HT 2-3, Control of R\&D Activities \\
\end{tabular} & $\begin{array}{l}x \\
x \\
x\end{array}$ \\
\hline Design Control & & $\begin{array}{c}\text { DWP\&HT 3-1, Design Control, Calegory I\&II } \\
\text { Projects Implementation Statement } \\
\text { DWP\&HT 3-3, Division Managed Tasks }\end{array}$ & \\
\hline Procurement Document Control & & DWP\&HT $4-1$, Procurement & \\
\hline $\begin{array}{l}\text { Instructions, Procedures and } \\
\text { Drawings }\end{array}$ & $\mathbf{x}$ & DWP\&HT 5-1, Procedures/Instructions & $\mathrm{x}$ \\
\hline Document Control & $\mathrm{X}$ & DWP\&HT 6-1. Document Control & $\mathrm{x}$ \\
\hline $\begin{array}{l}\text { Control of Purchased ltems and } \\
\text { Services }\end{array}$ & & DWP\&HT $4-1$, Procurement & \\
\hline Identification and Control of ltems & $x$ & DWP\&HT $8-1$, in and Control of liems & $x$ \\
\hline Control of Processes & & DWP\&HT 9-1, Control of Processes & \\
\hline Inspection & & DWP\&HT 10-1, Inspection & \\
\hline Test Control & & DWP\&HT 11-1, Test Control & \\
\hline $\begin{array}{l}\text { Control of Measuring \& Test } \\
\text { Equipment }\end{array}$ & $\mathrm{x}$ & DWP\&HT 12-1, Control of M\&TE & $i$ \\
\hline $\begin{array}{l}\text { Packaging, Handling, Shipping \& } \\
\text { Storage }\end{array}$ & & $\begin{array}{l}\text { DWP\&HT 13-1, Packaging, Handling. } \\
\text { Shipping \& Storage }\end{array}$ & \\
\hline $\begin{array}{l}\text { Inspection, Test, and Operating } \\
\text { Status }\end{array}$ & & $\begin{array}{l}\text { DWP\&HIT } 14-1 \text {, Inspection, Test, and } \\
\text { Operating Status }\end{array}$ & \\
\hline $\begin{array}{l}\text { Control of Nonconforming Items \& } \\
\text { Action }\end{array}$ & $\mathrm{x}$ & $\begin{array}{l}\text { DWP\&IIT } 15-1 \text {, Control of Nonconforming } \\
\text { Items and Activities }\end{array}$ & $x$ \\
\hline Corrective Action System & $\mathbf{x}$ & $\begin{array}{l}\text { DWP\&HT } 16-1 \text {, Corrective Action } \\
\text { Implementation Statement }\end{array}$ & $\mathrm{x}$ \\
\hline Quality Assurance Records & $\mathbf{x}$ & DWP\&IIT 17-1, QA Records & $x$ \\
\hline Audits & $x$ & $\begin{array}{l}\text { DWP\&IT } 181 \text {, Audits \& Surveillances } \\
\text { Implementation Statement }\end{array}$ & $x$ \\
\hline Software Quality Assurance & & DWP\&HT 20-1, Software Control & \\
\hline & & & \\
\hline
\end{tabular}


S. D. Fink -3-

WSRC-RP-93-1342

\section{RECORDS}

The following items shall become records for this technical task:

1. Technical Task Request, HLE-TTR-93-077

2. Task Technical Plan (Ref. ?)

3. Task Quality Assurance Plan (this document)

4. copies of laboratory notebooks or applicable pages

5. reports to customers

6. other supporting documentation deemed appropriate by the task leader.

\section{REEERENCES}

1. J. E. Marra, "Tank Level Program Action Plan (U)," HLW-HLE-931291, Rev.0, August 31, 1993.

2. J. E. Marra, Technical Task Request HLE-TTR-93077.

3. D. D. Walker, C. L. Crawford, and N. E. Bibler, "Radiolytic Gas Generation in Salt Cake, Technical Task Plan (U)," WSRC-RP-93-1341, August 29, 1993.

\section{APPROVALS}

\begin{tabular}{cc} 
(tmact $(i)$ tons & $10-1 /-93$ \\
\hline S. D. Fink, Manager, IWTS-LWP & Date
\end{tabular}

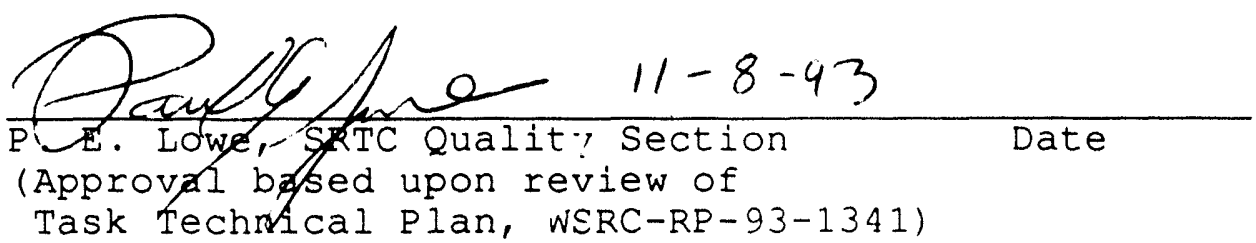

CC: $\quad$ P. E. Lowe, 773-42A

L. M. Nelson, 773-43A

IWT-LWP Files, 773-A

TIM, 773-52A (4) 

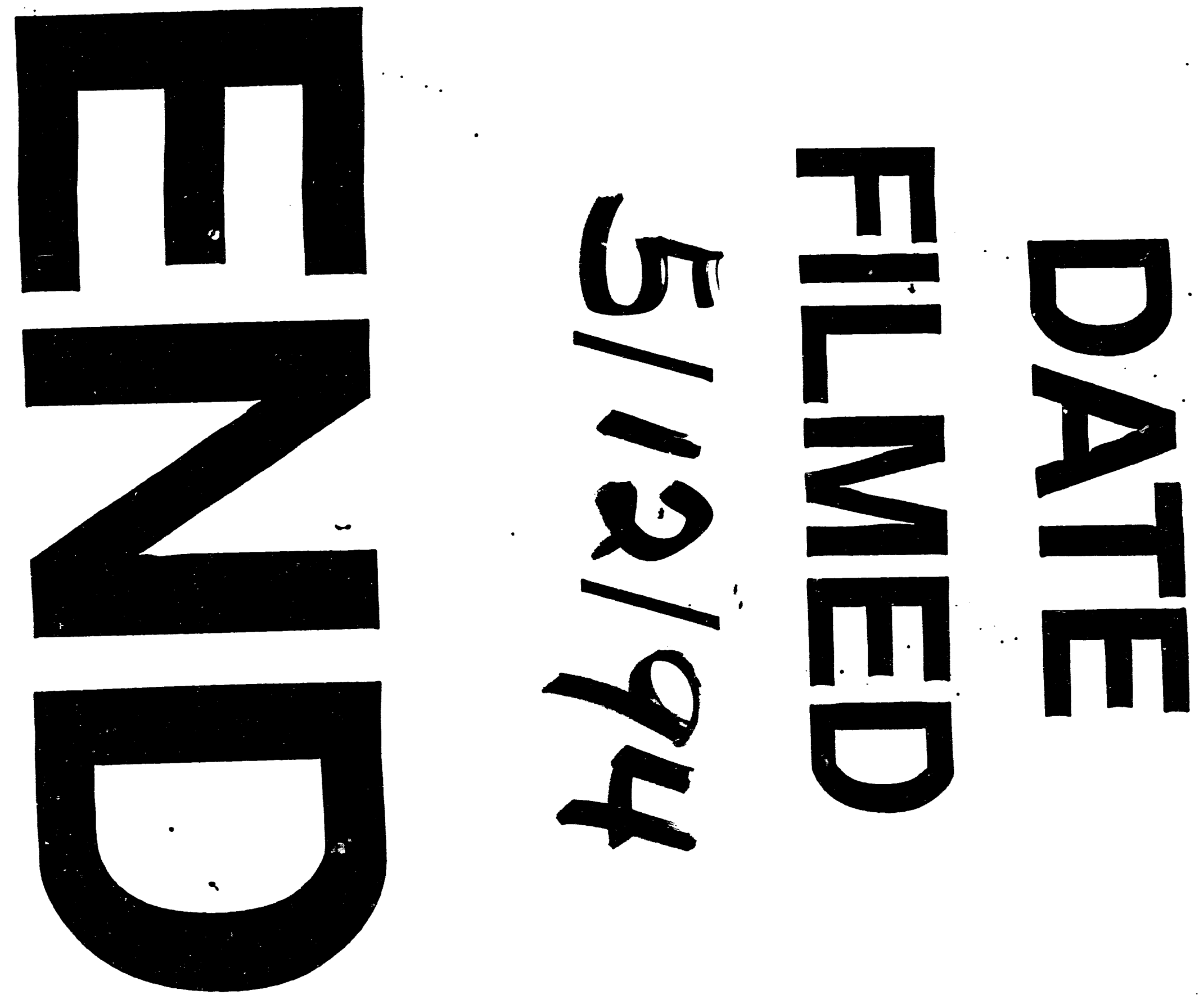
